Submitted to Renewable \& Sustainable Energy Reviews

$6^{\text {th }}$ May 2015

\title{
Geothermal Barriers, Policies and Economics in Chile - Lessons for the Andes
}

Pablo Sanchez-Alfaro ${ }^{1,2}$, Gerd Sielfeld ${ }^{3,2}$, Bart Van Campen ${ }^{4}$, Patrick Dobson ${ }^{5}$, Víctor Fuentes $^{4}$, Andy Reed ${ }^{6}$, Rodrigo Palma-Behnke ${ }^{7,8}$, Diego Morata ${ }^{1,2}$

${ }^{1}$ Department of Geology, Universidad de Chile, Santiago, Chile

${ }^{2}$ Andean Geothermal Center of Excellence (CEGA-FONDAP 15090013), Santiago, Chile

${ }^{3}$ Department of Structural and Geotechnical Engineering, Pontificia Universidad Católica de Chile

${ }^{4}$ The Geothermal Institute, University of Auckland

${ }^{5}$ Earth Sciences Division, Lawrence Berkeley National Laboratory

${ }^{6}$ Graduate School of Public and International Affairs, University of Pittsburgh

${ }^{7}$ Energy Center-FCFM, University of Chile

${ }^{8}$ Solar Energy Research Center (SERC- FONDAP 15110019)

Corresponding author:

Pablo Sánchez-Alfaro

Department of Geology,

University of Chile

Plaza Ercilla 803, Santiago, Chile

e-mail: vsanchez@ing.uchile.cl, Tel.:+56 29780627 


\section{Abstract}

The Andes is the largest undeveloped geothermal region in the world. The Chilean case is the most puzzling because the country is largely dependent on imported fuels causing, among other issues, high energy prices and energy dependency. But even though it has large quantities of geothermal resources which have been explored since the 1920s, no geothermal power plant has been constructed yet. The barriers for geothermal development in Chile have not been studied in detail and limited information is available about the real economic feasibility of geothermal power generation and whether effective incentives are needed for its development. In this study we present an integrated analysis of geoscientific, economic, historical and regulatory aspects of geothermal development in Chile based on the compilation of new and previously published data. Through a survey of key participants from government institutions, industry and academia we identified the main perceived advantages, barriers, and efficient incentives. The absence of clear medium-to-long term energy policies and a lack of government incentives for companies to overcome financial risk are perceived as the main barriers. Additionally, we calculated the estimated average Levelized Costs of Energy (LCoE) of geothermal electricity generation using different scenarios to illustrate the potential impact of possible government policies. At present conditions and without incentives we estimated a base case geothermal LCoE in Chile which would be "near competitive" compared to the average contract prices. Further analysis would be needed to estimate the effect of different policy incentives more rigorously. Finally, we propose some guidelines for geothermal stakeholders to encourage geothermal power development; these might prove useful to other Andean and developing countries as well. 
Keywords: geothermal; barriers and incentives; LCoE; Chile; Andes; energy policies; economy

\section{Introduction}

The western coast of South America hosts abundant geothermal resources related to the Andean volcanic arc, which could provide a clean and sustainable energy source $[1,2,3]$. This energy source is also attractive because of its high capacity factor and economic characteristics (low variable costs) and that it can be used to power base load generation. Even though exploration campaigns started in the early 20 th century, no geothermal power plant has been constructed in Chile yet [2]. The Chilean case is puzzling on initial inspection because electricity generation is largely dependent on imported fossil fuels and hydropower. Imported fuels are subject to global price fluctuations and hydropower is vulnerable to cyclic drought [4]. As a result, Chile has a non-diversified and insecure energy matrix with high price risk [5]. Moreover, Chile has some of the highest prices of electric energy in the region [5] and, over the last few years, social and environmental conflicts related to other types of energy projects have increased.

Renewable energy resources in Chile (geothermal, hydro power, solar, and wind) $[5,6]$ have tremendous potential and recent studies estimate an economically feasible geothermal resource of 3,350 MW [2, 7], i.e., representing $26 \%$ of the current total installed capacity of all resources (13,000 MW).

Other countries that have successfully developed geothermal resources often have had clear and direct policies designed to encourage geothermal development $[8,9$, 10]. Emblematic examples of countries that have successfully exploited geothermal resources are New Zealand, the U.S.A., the Philippines and Iceland [9, 11]. Although 
each country has had its own history of geothermal development, there are some common policies, such as the government's active participation in the identification and discovery of commercially viable geothermal resources, which have helped to reduce financial risks for potential developers $[9,10]$. In this sense, the International Energy Agency encourages governments to develop holistic geothermal policy frameworks which encompass economic considerations, regulation needs, market facilitation, and research and development support [5]. For the Chilean case, some published studies and institutional internal reports have identified and described some of the barriers of geothermal energy development $[12,13,14]$. However, most of these works offer partial, confidential, and generic data, and lack a systematic analysis of the information. In order to present an integrated analysis of historical, political and technical aspects of geothermal development in Chile, we have reviewed, discussed and synthesized published studies. We have also identified the main perceived advantages, barriers, and incentives (existing and potential) related to geothermal development, assessing their relevance and feasibility through a survey to propose guidelines for geothermal stakeholders. Furthermore, by using a simple economic model, we estimate the impact of some of the potential incentives on the levelized cost of geothermal energy. At the same time, we analysed unpublished data providing information on the geological-geothermal Andean context, including current geothermal projects and the estimated cost to produce geothermal energy in Chile. In this way we aim to facilitate geothermal power development and contribute to the debate about renewable energy in Chile. Lessons learned from the Chilean case could be extended to other Andean and developing countries. 


\subsection{Geothermal energy}

Geothermal energy is the energy contained as heat in the Earth's interior [15]. Along major tectonic plate boundaries where earthquakes and volcanoes are concentrated, heat flux is anomalously high, increasing the geothermal gradient above the average $\left(30^{\circ} \mathrm{C} / \mathrm{km}\right.$ of depth). High heat flux occurs along the volcanic arcs of convergent plate margins like the Andes, promoting the genesis, segregation, ascent and emplacement of magmas through the crust, expressed at the surface as active volcanoes [16]. In this geodynamic setting, the development of high enthalpy geothermal systems at shallow depths $(<3 \mathrm{~km})$ occurs [17], often permitting the exploitation of these resources under economically feasible conditions.

Natural geothermal systems (Fig. 1) result from the interaction between [15, 16, 18]: (1) a heat source, such as a shallow $(<7 \mathrm{~km})$ magma body cooling and releasing heat; (2) cold fluid recharge, such as groundwater and/or meteoric water (3) permeable pathways allowing fluid flow, such as fracture networks (4) hot fluids, composed of degassing magmas and recharge water that has flowed through hot rocks; (5) a geothermal reservoir, consisting of a permeable host rock where hot fluids can accumulate; and, (6), an impermeable cap at top of the reservoir, consisting of clays generated in situ by hydrothermal alteration of the host rock. In areas where magmatic activity does not exist, the heat accumulation may be due to particular geological conditions of the crust such as radioactive decay producing an anomalously high geothermal gradient or regional extension resulting in shallow crust and high heat flow [17].

Over many centuries, people have used geothermal water from hot springs for cooking, medicine and relaxing. For electricity generation, hot fluids from the 
geothermal reservoirs are extracted by deep wells, utilizing produced steam to power turbines in the power plants.

The main characteristics of geothermal resource use for electricity generation are: (1) renewable and sustainable electrical generation made possible by reservoir management techniques; (2) high capacity or plant factors $(0.8-0.95)$ that ensure continuous base-load generation; (3) high initial costs and investment risks in preliminary exploration and development phases; (4) low operation costs and relatively low levelized costs of electricity (LCoE); (5) low greenhouse gas (GHG) emissions, limited environmental effects and minimal land use requirements with respect to conventional energy sources; (6) each geothermal system is unique and high-grade geothermal resources have restricted geographic distribution; (7) competitive costs are generally achieved with a favourable public policy framework; (8) exploration and exploitation of the resource use mature and well-understood technology; (9) power plants have modular designs and (10) mid-sized greenfield projects (50 MW) require c.a. 7-12 years for development. These are advantages or barriers, which vary in their influence depending on the geological-energetic framework. For reviews on geothermal technology [15], the history of geothermal uses [19], geothermal electricity projections [20], direct uses [21], costs of geothermal energy [22] and sustainability of geothermal resources [23], refer to specific references.

\section{Historic analysis of geothermal exploration in Chile}

Based on previous studies $[2,24,25,26]$ we present a synthesis of the main activities, achievements and challenges related to geothermal energy in Chile (Table 1). The most relevant progress occurred in three stages led by different institutions: (1) 
1908-1923: Italian colony promotion; (2) 1968-1978: Chilean State investment; (3)

2000-present: Private investment with the Chilean Government acting as a regulator.

The history of geothermal energy in Chile started in 1908 in El Tatio, when the Italian colony of Antofagasta city (northern Chile) brought researchers from Larderello, Italy to carry out the first geothermal exploration program in the country. This revealed the enormous resources at El Tatio. However, the lack of economic support and technical issues (i.e. the blow out of the second well) halted exploration.

One of the most fruitful stages of geothermal exploration began at the end of the 1960s, when the Chilean State, with the assistance of the United Nations Development Programme and the Japan International Cooperation Agency, promoted research in the northernmost part of the country $\left(17^{\circ}\right.$ to $\left.24^{\circ} \mathrm{S}\right)$ aiming to supply energy for the growing mining industry. A Committee for Geothermal Use was created and this effort resulted in the training of Chilean researchers, the detailed exploration of Puchuldiza [27] and El Tatio [28], and the conclusion that a power generation plant was economically and technically feasible [24]. In 1978, the right to develop the El Tatio geothermal field was placed into an international bidding process, but this was unfortunately never completed because of abrupt policy changes following the change of goverment in that period. At the end of 1978 the systematic exploration of geothermal resources ceased and in 1983 the Chilean Committee for Geothermal Use was disbanded.

In 2000 the Chilean government enacted a Geothermal Law establishing a framework that permitted private and state-owned companies to develop geothermal projects $[25,29]$. Since then geothermal energy exploration in Chile has been active again. Production-diameter deep exploration wells have confirmed abundant resources in the Tolhuaca and Apacheta geothermal fields, which are awaiting financing before proceeding with field development and power plant construction. In parallel, the 
research initiatives led by the Andean Geothermal Center of Excellence (CEGA) and the Chilean Geological Survey (SERNAGEOMIN) have contributed to increase geothermal knowledge. However there are still many barriers that hinder geothermal energy exploration and exploitation, which have delayed and inhibited projects in Chile.

Thus, historical analysis indicates that the sporadic progress of geothermal exploration in Chile has resulted primarily from the existence or absence of public policies.

\section{Geology and exploration strategies for Andean and Chilean geothermal} resources

Chilean continental territory extends along the axis and western margin of the Andes, which is a long-lived mountain belt with an active volcanic arc. The current state of the Andean orogeny is characterized by: (1) transpressional tectonics, promoting the development of regional fault systems, thus resulting in an enhanced permeability structure; (2) the volcanic arc, with more than 95 active volcanoes and hundreds of surface geothermal features, and; (3) differential erosion rates related to the extreme dry climate in the northern region and the extreme wet climate in the southern region (Fig 2).

From a geological point of view, Andean high enthalpy geothermal resources could exist where three main factors are simultaneously present: (1) active magmatic heat-source (implying volcanic activity from 1 Million years to present); (2) secondary permeability associated with recently active fault systems (active faults, non-sealed and penetrative fault-fracture networks); in particular, transtensional tectonic style enhances secondary permeability and promotes fluid convection [17, 30, 31]; and (3) fluid recharge (groundwater and/or meteoric water). Based on these basic elements, Chile can 
be divided into the Northern, Central-Southern Chile and Flat-Slab Geothermal Regions. Besides the particular geological conditions, each of these regions has specific social and technical issues (Fig. 2). Therefore, exploration strategies should consider the following particular aspects:

Northern Chile Geothermal Region: Focus exploration in or nearby Pleistocene (c.a. 0.8 -0.2 Ma) volcanic systems, where young volcanism and active transtensional fracture and fault systems are present. Geochemical fluid analyses have to consider the presence of evaporites in the bedrock sequence and develop methodologies that could distinguish evaporitic from geothermal signals. The distance to the main electricity grid is critical for total cost calculation. High elevation needs to be considered for exploration and operational logistics.

Flat Slab Geothermal Region: Scarce availability of information needs to be carefully analysed, and many basic geologic and geothermal research have to be done first. The lack of recent volcanic activity makes finding high enthalpy geothermal systems more challenging. Seismogenic-fault controlled geothermal systems have to be found first. Logistically, high elevation and severe climate conditions need to be considered.

\section{Central Southern Geothermal Region: Focus exploration in or nearby} Pleistocene (c.a. 0.8 -0.2 Ma) volcanic complexes and clusters, especially in areas where active transtensional tectonics take place, such as regional fault linked damage zones, tips or intersections. Extreme wet climate (high precipitation) implies that geochemical fluid analyses have to consider the provenance of waters and be careful of dilution of geothermal fluids by non-geothermal aquifers. Logistically, exploration phases have to be organized to avoid the wintertime, when extreme winter weather 
conditions make operations hazardous and costly. Road construction needs optimal and detailed designs for abrupt and irregular landscape.

\section{Potential, projections and status of geothermal electricity generation in Chile}

\subsection{Geothermal potential and projects}

Lahsen (1986) conducted a preliminary assessment of the geothermal potential of Chile, arriving at an estimate on the order of 16,000 MWe [1]. More recent regional estimations considering only the already explored prospects obtain a more conservative potential resource estimate of 3,350 MWe [2,8]. Detailed estimations based on the most advanced geothermal projects range from 1,000 MWe to 1,950 MWe [2], which should be considered as the minimum economically feasible potential estimate. The already proven potential is $30 \mathrm{MWe}$, measured during well tests of the three most advanced

prospects (El Tatio, Pampa Apacheta, and Tolhuaca). In the context of scarce publically available data, the use of improved measurement and assessment techniques is needed to supply more accurate projections.

Currently geothermal exploration and development projects in Chile are very active, with 76 concessions granted for exploration and 6 concessions for exploitation by mid-2012. Most of the concession areas exhibit moderate to high temperature geothermal features. Current exploration activities include geological, geophysical and geochemical surveys, volcanological studies and also the drilling of deep wells to confirm the presence of a geothermal resource. Exploitation concessions involve the drilling of additional wells to delineate the extent of the geothermal resource. The main geothermal exploration projects are described in Table 2.

Three of the exploitation concessions, El Tatio, Pampa Apacheta (Cerro Pabellón), and Tolhuaca, have progressed to the stage of having multiple successful 
exploration wells with confirmation flow tests, but none of these projects has progressed to the stage of power plant construction. The El Tatio project had an uncontrolled well discharge in 2009, and environmental concerns related to this incident have led to the suspension of geothermal development at this site [32]. The Tolhuaca concession was originally explored by Geoglobal Energy, which drilled a total of four wells at the site and had a well test with flow equivalent to $12 \mathrm{MWe}$ [32], but this concession was later transferred to Mighty River Power, which announced its intention in Dec. 2014 to sell this asset. The only project that appears to be advancing is the Cerro Pabellón project (Pampa Apacheta), where ENEL Green Power and ENAP have announced plans in Feb. 2015 to move forward with a 50 MWe development. The lack of significant progress after more than a decade of active geothermal exploration in Chile may result from many of the barriers to geothermal development discussed in the following section.

A detailed and updated description of geothermal resources in Chile and South America can be found in $[32,33]$.

\section{Perceived advantages, barriers and incentives for geothermal development}

To identify, rank and analyse the main perceived advantages, barriers and incentive for geothermal development of geothermal development in Chile, we created a standardized questionnaire with a list of 58 advantages, barriers and incentives to be ranked (details in [34]). The questionnaire is based on a literature review of geothermal policy studies, including $[9,10,11,12,35,36,37,38]$. Each person interviewed rated the advantages, barriers and incentives on a scale of 1.0 (irrelevant) through 5.0 (very important). We also analysed the barriers and incentives not included in the questionnaire but repeatedly mentioned by the respondents. More than 30 participants in the Chilean geothermal sector were interviewed. These individuals were grouped into three categories: Government, Industry, and Academia/other. Tables 3 and 4 summarize 
the results of the survey and the potential policy solutions, which are discussed in the next subsections.

\subsection{Advantages of exploiting geothermal resources in Chile}

Results in Table 3 indicate how participants in each of the three sectors perceive the strengths of geothermal development in Chile. On average, geothermal energy's most significant perceived advantages were identified as its high capacity factor, its domestic availability, and its abundance, which are directly related to increasing energy security and independence. Contrasting with other countries' experiences, cost was considered a disadvantage to geothermal development in Chile. With insufficient government financial support and a framework that allows for higher degrees of uncertainty in the sector, a majority perceived the cost at which geothermal energy could be produced in Chile to be a significant challenge.

\subsection{Barriers and incentives for geothermal development}

\subsubsection{Financial and economic barriers}

(a) The cost for geothermal exploration in Chile is higher than in other countries and therefore despite the worldwide favourable and competitive cost for geothermal energy, proving a resource's viability is both expensive and risky in Chile. Therefore, few investors are willing to assume this risk in an unproven market and may require some level of additional assistance, but the Chilean government does not offer financial incentives (yet); (b) There are only two firms available that provide necessary exploration drilling equipment, but they charge very high prices for their services; (c) Many geothermal resources are in remote areas and there is a lack of access to the existing electrical grid.

Although all the stakeholders (industry, academia, government) agree on the relevance of the risk of the investment as a barrier, there is partial disagreement on 
possible solutions (Table 4). On average, those interviewed from industry and academia think that subsidizing failed wells in exploration stage, and providing feed-in tariffs (price guarantees) for geothermal energy and increased tax benefits for geothermal developers would be strong incentives. In contrast, government respondents only agreed with the benefits of subsidizing failed wells. A potential carbon tax received low ratings from both government and industry while those in academia rated a carbon tax as a stronger option. Most of the interviewed agreed that the scarcity of drilling rigs and crews results in very high drilling costs and hinders geothermal exploration. However, only the government and academia respondents perceived that providing financial incentives to attract more service providers to the market to support its technical needs would be a strong incentive. The remoteness of some geothermal resources and the associated problems to access the electrical grid is considered a strong barrier. In that sense, any steps taken that would ensure the construction of necessary transmission lines and infrastructure were viewed as very valuable.

\subsubsection{Legal/Regulatory Barriers}

(a) The existing regulatory framework has allowed many speculators to obtain geothermal concessions, thus delaying the development of viable prospects. The reason is that concessions are often granted based on a firm's promised investment rather than its ability and capacity to implement a geothermal project; (b) Lack of a clear and comprehensive legal framework to regulate disputes between geothermal developers and entities that own the rights to other resources within the concession (i.e., indigenous claims, local communities, etc.). Developers often enter costly and lengthy negotiations with landowners and/or communities for access to the site; (c) The possibility that several companies own different concessions related to a single geothermal resource (as might be the case of Puchuldiza) can strongly affect the development of the project; (d) 
Inflexible concession requirements on the duration and areal dimensions. Some variables that affect the process of exploration are not considered in current stipulations in concession law; (e) Environmental impact studies are not uniform and create project delays. Those who conduct and evaluate the studies are often not geothermal experts. Environmental impact studies are conducted only when a project enters the period of exploitation, not considering possible damage during exploration stage. Moreover, the lack of 'baseline' studies could lead to the mistaken conclusion that natural changes in the dynamic thermal features could be attributed to exploration/exploitation activities. Initiating environmental impact studies at the start of exploration activities also provides geothermal developers with an opportunity to engage with the local community. Most of these issues have been identified in other countries (e.g., USA; [39, 40]), but after years of geothermal energy production, nations have made more user-friendly regulatory environments for development [9].

Those interviewed in industry and academia found the current legal and regulatory framework in Chile to be inadequate and felt the government could improve it on both national and regional levels. However, this barrier is surprisingly undervalued by the government respondents, who seem to perceive that existing regulations are perfectly clear. The ambiguity concerning the potential sharing of a single reservoir by many companies is considered a strong barrier for all stakeholders. Many interviewees from industry felt that the technical evaluation conducted during the bidding processes was insufficient due to the scarcity of qualified staff, resulting in the granting of concessions to speculators. Also, the industry seems to be heavily concerned about delays related to the environmental impact assessment system and the inflexibility of the duration and areal dimensions of the concession. 
Respondents provided several suggestions on how the government could improve the concession application and environmental review processes, including: (1) Requirement of technical expertise for concession applicants: To avoid granting concessions to speculators; improve the technical and professional evaluation mechanism in the geothermal concession approval process. For that it would be necessary to re-evaluate the law and describe in greater detail the technical requirements developers must meet to receive a concession; (2) The flexibility of the Concession: Increase the two-year period for exploration concessions located in areas with extreme climates and in environmentally or culturally sensitive areas, where additional time may also be necessary to appropriately address concerns from local communities; (3) Environmental Impact Studies: Revaluate both the standards of these evaluations and the personnel who are responsible for doing these studies for geothermal projects. Environmental impact studies should start at the beginning of the exploratory phase; (4) Incorporation of the spirit of International Labor Organization Convention (ILO) 169 “The Indigenous and Tribal Peoples Convention" into Geothermal Law 19.657 which was ratified by Chile in 2008. Increasing the clarity about indigenous issues and rights in Chile's legal and institutional framework might decrease the high level of uncertainty and risk in the geothermal sector. The example of tribal-industry partnerships formed for many geothermal projects in New Zealand might be considered [41].

\subsubsection{Institutional Barriers}

(a) There is a general lack of direction within the government with regards to geothermal resources; (b) Some government institutions are out of synchronization on geothermal issues; (c) Some concessions are granted only after a lengthy approval process, long beyond the period noted in the Geothermal Law. The reason is that there 
are few geothermal professionals working in government, and these experts are widely scattered.

Those interviewed in industry and academia, on average, find that there is a lack of direction in the national energy policy, which is a relevant barrier for development. They also consider that there are not enough human resources dedicated to geothermal regulation/promotion in government institutions and that this might cause delays in obtaining approval for granting concessions. Government respondents indicated that these barriers are irrelevant or non-existent. However, there was a consensus among all those interviewed that a clear vision of the role that geothermal energy will play in Chile's future energy mix is required. The proposal of providing additional human or technical resources to ensure that concessions are granted in a shorter period of time were highly valued by industry and academia, but not by those from government. The industry and academic respondents indicated that geothermal management and regulation activities should be consolidated in one government office and sufficiently staffed with professionals who are knowledgeable about geothermal projects.

\subsubsection{Educational, Information, and Social Barriers}

(a) Only a few universities in Chile have academic programs associated with geothermal energy and these existing research centers were recently created, and thus do not have a long history of working with industrial partners; (b) Much data about exploration and resources remains in the hands of private companies, restricting the findings of research institutions; (c) Due to lack of education and outreach, communities may consider geothermal exploration/exploitation as a threat [42].

Those interviewed in government and academia considered that both the lack of research centers and the limited access to information are strong barriers. On the other hand, those from industry considered that neither of these barriers is relevant. 
Government and academic respondents indicated that one way to increase the diffusion of knowledge on geothermal systems in Chile would be to have government research institutions engage in their own research projects and to require companies to provide the results of their exploration activities if a concession is abandoned or if a concession for exploitation is granted. In contrast, people from industry are not keen to share their data with research centers and do not think these would be strong incentives. Most of the industry responses indicated that there was little incentive for them to provide their exploration results in exchange for financial assistance from the state. These responses might reflect a perception that industry does not need to interact with either academic or governmental research institutions and might explain the lack of interest on the part of industry to develop research programs in collaboration with academic institutions. This point of view precludes international experience showing the good results of partnership between industry and university/government research efforts [9].

Most of those interviewed indicated that public opinion may view geothermal exploration/exploitation as a threat, and that this could pose a strong barrier to geothermal resource development efforts. Many respondents considered that a public awareness campaign to demonstrate the potential economic, environmental and social benefits of geothermal energy would be strongly positive. The industry was the only stakeholder that considered a framework for economic and social development in communities near geothermal projects would not be a strong incentive. Moreover, industry is not keen to develop geothermal direct use projects to benefit communities living nearby geothermal fields. 


\section{Geothermal economics in Chile}

Chile is a country with many energy resources (geothermal, solar, wind and hydro-power), but imports $89 \%$ of fossil fuels consumed, affecting the security of electric energy supply as revealed in 2004 by the supply shortfall of low cost Argentinean gas [5, 43]. Additionally, fossil fuels have significant negative effects on the health and welfare of society and the environment $[44,45]$. The historic reliance on large hydropower plants makes the electric system vulnerable to disruptions driven by drought, as has occurred in recent decades [46]. In this context, geothermal generation represents a particularly interesting and potentially competitive opportunity.

Having looked at the main perceived barriers to geothermal development in the previous chapter, this economic chapter very briefly reviews: 1) Chilean electricity market and support mechanisms; 2) Chilean geothermal economics and potential 'economic incentives'; 3) Modelling of costs and 'stylized policy impacts'. The costs of geothermal are modelled with a simplistic, stylized model, which nevertheless seems to support the present 'market situation' that geothermal in Chile seems 'near-but-notfully-economic' yet. More detailed analysis is recommended and planned for the future.

\subsection{Chilean electricity market and support mechanisms}

Chile pioneered electricity market liberalization in the 1980s. It has changed in part over the years, but maintained its main design features (details in [47, 48, 49]) including: (1) Two main transmission grids: SIC in central-southern Chile and SING in northern Chile; (2) independent, private electricity generators; (3) centralized dispatch (including optimal long-term hydropower operation -modelling), (4) a generator-only wholesale market to 'trade' short-term differences and (5) long-term contracts with large users (especially mining companies) and regulated distributors (who on-sell to 
smaller end-users). Average 2010-2014 contract prices for regulated customers in SIC were US\$ 82.6/MWh with future contract prices varying from US\$ 93 to $\$ 125 / \mathrm{MWh}$ [50].

Geothermal power, as a low-carbon-emission, renewable resource, can often derive additional income from other sources. For example, Non-Conventional Renewable Energy Credits (NCRE-credits) and Kyoto/Clean Development Mechanism $(\mathrm{CDM})$ credits are both applicable in Chile. Whereas the latter provided a valuable source of income for some wind energy projects in Chile in the past, recent stagnation of international climate change treaty negotiations has meant that these credits have little value at present. Chile has chosen to focus its renewables policies on diversifying the electricity supply matrix by setting minimum standards for NCREs in generationportfolios (a quota scheme based on a percentage of energy supplies plus a fine in the case of non-compliance) and opening an informal market for trading in NCRE-credits between generators (comparable to RPS and 'white certificate trading' in other jurisdictions). Initially the NCRE- $\%$ was set at $5 \%$ with linear growth to $10 \%$ in 2020 ; this target has been systematically met with new biomass, mini-hydro, and wind energy projects. The observed NCRE-credits among generators were effectively capped by the 'non-compliance fine' of US\$25/MWh. Last year a new law was passed (Short Law 20,698, also called Law 20/25) which increases the NCRE-target to $20 \%$ in 2025. As the law is phased in, the expectation is that NCRE prices will start rising.

\subsection{Chile geothermal economics and policy incentives}

Geothermal projects and power development costs vary around the world depending on resource temperature and pressure, reservoir depth and permeability, fluid chemistry, location, drilling market, size of development, number and type of plants (dry steam, flash, binary or hybrid) used, and whether the project is a greenfield or a 
brownfield/expansion. New geothermal plant generation costs can therefore vary significantly, from US\$ 50-70/MWh (for brownfield expansions in New Zealand [51]) to US\$120/MWh in USA for greenfield development and to US\$ 200/MWh in Europe, for deep, low-medium temperature projects [52]. As Chile hasn't developed any geothermal power projects yet, estimation of Chilean geothermal costs needs some understanding and extrapolation. A few recently explored and licensed geothermal prospects, and comparison with international geothermal project economics can give some insights into the most significant cost factors and why these seem to be higher in Chile (details in [47]).

\subsubsection{Capital costs}

a) Geothermal exploration and drilling is not the highest cost (normally tens of millions for production well diameter exploration drilling), but is often seen as the most risky part of geothermal development. Chile's geothermal resources are often remote and at high altitude (e.g., [53]), and the costs of drilling and associated infrastructure is therefore estimated to be a factor of 2 higher than the international average. This is exacerbated by the fact that there are few permanent geothermal drilling rigs in the country, driving up drill rig mobilization costs and lowering competition. There might be a strong chickenvs-egg effect between the low geothermal drilling activity, high costs and the lack of a critical mass for drilling companies to decide to permanently base geothermal drilling rigs in Chile.

b) Geothermal power plant and transmission investment decisions are made after exploration, by a time that risks should have been brought down and power plant construction and operation should be 'relatively straightforward'. Still some of the remote, rugged country and high-altitude operation conditions in 
The Andes (Fig. 2) might provide engineering design and execution challenges, which are likely to drive up costs. Another significant investment cost factor could be transmission investments: most geothermal sites in Chile are remote from demand and main transmission lines. Under the Chilean market rules, individual projects are themselves responsible for connection to the main transmission line and associated investments. Geothermal projects -which are initially small (ranging 50 to $75 \mathrm{MWe}$ ) can often be $75 \mathrm{~km}$ or more away from the nearest transmission line. However, commonly there are opportunities in the area for other NCRE projects (such as small-hydro and solar) and successful geothermal projects are expected to expand in the future, providing for the possibility of different projects partnering on shared transmission facilities. Therefore, government policies could assist in bringing down capital costs, e.g., sharing of transmission investment, 'pooling' of drilling equipment, and other costly exploration activities (e.g., geophysics).

\subsubsection{Risks and discount rates}

Apart from the capital costs themselves, one of the main factors affecting the economics of geothermal generation, is the discount rate (or Weighted Average Costs of Capital). Low-risk brownfield expansions in countries with existing geothermal experience like New Zealand develop relatively low cost geothermal power. In a country like Chile, where companies have to invest in risky greenfield projects in a market unfamiliar with such projects, risks - and therefore required discount rates (WACC) - are expected to be considerably higher. Government policy options could be around drilling insurance, co-investments, enhanced depreciation and other financial instruments.

\subsubsection{Renewable portfolio standards}


Chile has recently strengthened its '20/25' NCRE-law, which is likely to lead to steadily rising incentives for renewable sources of energy. Proposed use of governmenttendering for long-term NCRE-credit contracts would not necessarily increase the price, but would add long-term price certainty, which could be seen as a risk-reducing instrument that could help geothermal projects significantly by allowing better access to financing mechanisms.

\subsection{Levelized costs of geothermal energy and policy incentives}

To estimate geothermal cost variations and illustrate the potential effect of government interventions, the authors have used a simple LCOE-model (details in [47, 48]). Levelized Costs Of Energy (LCoE) is a concept to calculate the total life cycle costs of a plant (investment, fuel, O\&M), discount these back to a common base year, and divide by the total generation to come to average long-run costs per MWh (e.g., [54, $55,56])$. This type of tool can be used to both study cost sensitivities and to analyse the potential impact of policies.

a) Capital costs: a base case investment cost of US\$ 4,500/kWe installed geothermal capacity is used with a $\pm 10 \%$ range for capital cost variation and policy sensitivity. This value is based on the investment cost reported for the environmental assessment of the Tolhuaca (US\$ 4,714/kWe for $70 \mathrm{MW}$ ) and Cerro Pabellón/Pampa Apacheta (US\$ 3,600/kWe for 50 MW) projects.

b) Risks \& discount rates: a base case of $12 \%$ (real) discount rate is used with a range from $9 \%$ to $15 \%$ for risk variation and policy sensitivity.

c) NCRE credits: a base case of US\$10/MWh is used, with a range from 0 to US\$ 25 per MWh.

The results of the LCOE analysis in Fig. 3 are compared to an average contract price in SIC (ASCP) of US\$ 82.6 per MWh. At present (with estimated base factors of US\$ 
4,500/kWe, a $12 \%$ discount rate, and NCRE credits at US\$10/MWh), geothermal power costs seem 'near-competitive' (US\$ 94.91/MWh without NCRE credits; US\$

84.91/MWh with NCRE credits). The three policy incentive/sensitivity scenarios illustrate that government policies can have a significant impact on geothermal economics. More detailed analysis would be needed to calculate the exact effect of different policy measures.

\section{Guidelines for geothermal stakeholders}

Based on a holistic analysis and considering the perceived barriers and incentives we recommend that stakeholders engage in the following short and long-term actions to realize the true benefits of Chile's geothermal resources:

\subsection{Policy makers (Government agencies \& Congress)}

1. Provide a vision or plan for geothermal development. Support this plan with more active communication with developers and by employing an increased number of geothermal experts in government institutions to more effectively support sector regulation and development.

2. Reduce the financial risk in geothermal development. In the short term, options could be to subsidize unsuccessful wells in the pre-feasibility stage (higher subsidies for unsuccessful wells in the first attempt, decreasing for further attempts) as it has been successfully applied in Italy, Iceland, New Zealand and the Philippines [e.g. 9, 11, 36]. After the implementation of common agreement incentives, assess in detail the effect of other economic and regulatory incentives to define priorities.

3. Engage in a national geothermal resource assessment supported by new geological, geochemical, and geophysical data (heat flow, resistivity, 
geochemistry of fluids, etc.). Evaluate resources on economic, social, and environmental terms.

4. Revise and improve the geothermal concession law to solve legal issues (e.g., one reservoir split in two concessions), to account for local community needs, to clarify environmental impact study requirements, and to consider the unique environmental and/or social issues that impact geothermal development in certain regions of the country.

5. Revaluate the current concession granting process to find ways to make it more comprehensive by including both technical and environmental evaluations. At the same time, the process will need to be streamlined.

6. Provide more long-term support for research and development initiatives. Create an institutional framework in which geothermal information can be shared between industry, government, and universities. This research could lead to reduced exploration risk through improved targeting of exploration wells.

7. Carefully consider the location of geothermal resources and projects in any future government initiatives related to energy transmission, and encourage collaboration with other renewable energy projects.

8. Consider other support mechanisms, like exploration equipment pooling, transmission support and enhanced NCRE-mechanisms.

\subsection{Geothermal companies}

1. Participate in cooperative initiatives and common goals with government institutions - particularly in terms of sharing information, research, and needs.

2. Create industry-wide standards for interacting with local communities near project sites; including consulting local inhabitants before initial activities and conducting baseline assessment of natural variations in geothermal systems. 
3. Initiate local development projects related to direct uses of geothermal resources (e.g., greenhouses, district heating, aquaculture, food \& wood dryers) and/or create community foundations to ensure local inhabitants who may be affected by development are compensated and have a stake in the success of the project.

4. Develop ways to lower the cost of drilling through the development of incountry infrastructure to support the Chilean geothermal industry, where multiple drilling rigs would be available for conducting exploration and development of geothermal resources.

\subsection{Universities and research institutions}

1. Create study programs that provide students with the technical capacity to work in the geothermal sector. Also, increase outreach activities to educate society about geothermal energy.

2. Develop an Andean geothermal system model as well as research in technological development. Adapt existing technologies to Andean conditions (e.g., high altitude, water scarcity).

3. Engage in a public awareness campaign to ensure that citizens understand the benefits and nature of geothermal projects.

4. Engage both government and industry to expand sharing of geothermal resource information and act as a platform for communication and exchanges between all groups.

5. Support and advise policymakers on the creation of financial incentives and in the update of geothermal regulations.

\section{Conclusions}


The Andes is the largest unexploited geothermal region in the world. With few local fossil resources, but a vast geothermal potential (varyingly estimated from 3,000$16,000 \mathrm{MWe})$, geothermal energy can contribute to the development of a secure and sustainable electricity matrix in Chile. In spite of Chile having been at the forefront of Latin America geothermal exploration activities for decades, still no geothermal power plants have been constructed. This article is based on a detailed analysis and interviews with geothermal stakeholders to review the reasons and barriers for the slow progress. An initial, simplified economic impact analysis of these barriers and potential policies to relieve these barriers was presented. Considering that the rest of the Andean countries are even less explored and that most of them have a nascent institutional framework for geothermal energy, some lessons could potentially be learnt from the presented analysis on Chile.

Our historical analysis indicates that the progress of geothermal exploration in Chile has been strongly influenced by the existence or absence of public policies. Thus, to promote geothermal development, a clear policy framework has to be developed. Based on the nature of geothermal systems we identified three contrasting geothermal regions in Chile. Therefore, when planning exploration and exploitation strategies, the geological, technical and social differences for these regions should be considered.

The main perceived advantages of geothermal energy by industry, government and academia are the source's high capacity factor and its relative abundance in the country. Both of these factors potentially augment energy security. The main perceived barriers are related to (1) absence of clear policies and qualified staff in government institutions to manage geothermal development; (2) lack of incentives for companies to overcome financial risk in an unproven market; (3) complicated local, provincial, and national regulations; (4) high costs of conducting exploration and development drilling 
and (5) high cost of constructing transmission lines. At present conditions and without incentives we estimate a base case LCoE of geothermal in Chile around US\$ 94.91/MWh, which would be "near competitive" compared to the average contract price for the main grid (US\$ 82.6/MWh). The government policies could have a significant impact in decreasing such LCoE.

We propose several actions to overcome barriers for the different stakeholders for Chilean case. Some of these actions are fundamental to achieve the future projections for the development of geothermal energy in Chile. Therefore policy makers will need to determine the value of geothermal in the nation's future energy mix as a clean, secure and domestic energy source.

A follow-up for the article is being discussed with representatives of the Chilean government, leading to a more detailed economic analysis (including a multi-stage LCOE-model and multiple policy options) to explore the various policy options and their impacts further.

\section{Acknowledgments}

We acknowledge the support of CONICYT FONDAP Project 15090013 "Centro de Excelencia en Geotermia de los Andes, CEGA" and CONICYT International Network Program project REDES140036. We thank Alvaro Navarrete, Alfredo Lahsen and Jorge Clavero, who kindly contributed to an early version of this manuscript. P. Sánchez-Alfaro and G. Sielfeld acknowledge the support given by MECESUP UCH0708 and CONICYT doctoral grants, respectively. P. Dobson was supported by Lawrence Berkeley National Laboratory under U.S. Department of Energy, Assistant Secretary for Energy Efficiency and Renewable Energy, Geothermal Technologies Program, under the U.S. Department of Energy Contract No. DE-AC02-05CH11231. 
We thank the constructive comments of three anonymous reviewers that helped improve the manuscript.

\section{Figure captions}

Fig 1: Main feature of a natural geothermal system and a geothermal power plant. Geologic environment is extracted from generalized Andean arc type.

Fig 2: Main geological, social and technical characteristics to be considered for geothermal development in the three identified geothermal regions in Chile.

Fig 3: Levelized cost of geothermal energy in Chile for different scenarios. Base case is US\$ 4,500/kWe of Capital Cost (reported by private developers) and a $12 \%$ discount rate. The average contract price of the main electric grid (ASCP) is shown for comparison. Even without government incentives, geothermal energy has "near competitive" cost, especially when considering the NCRE-credits.

\section{References}

[1] Lahsen, A. Origen y potencial de energía geotérmica en los Andes de Chile. In: J.Frutos, R. Oyarzún, and M. Pincheira (Eds) Geología y Recursos Minerales de Chile, Univ. de Concepción, 423438. (In Spanish); 1986.

[2] Lahsen, A, Muñoz, N, Parada, MA. Geothermal Development in Chile. Proceedings World Geothermal Congress, Bali, Indonesia; 2010.

[3] Sánchez, P, Pérez-Flores, P, Arancibia, G, Cembrano, J, Reich, M. Crustal deformation effects on the chemical evolution of geothermal systems: the intra-arc Liquiñe-Ofqui fault system, Southern Andes. International Geology Review 2013;55:1384-1400.

[4] Pusschel, S, Palma, R, Campen van, B. Systematic tool to plan and evaluate demand side strategies during sustained energy crises in hydrothermal power systems; International Journal of Electrical Power and Energy Systems - IJEPES-D-13-01820R1; 2015.

[5] IEA International Energy Agency. 2009. Chile Energy Policy review 2009 [Online] Available: http://www.iea.org. [Accessed 2 2013].

[6] Guzowski, C, Recalde, M. Latin American electricity markets and renewable energy sources: The Argentinian and Chilean cases. International Journal of Hydrogen Energy 2011;35: 5813-5817. 
[7] Soffia, J, Clavero, J. Doing geothermal exploration business in Chile, Energia Andina experience. Geothermal Resources Council Transactions 2010;34:637-641.

[8] Fridleifsson, IB. Geothermal energy for the benefit of the people. Renewable and Sustainable Energy Reviews 2001;5(3):299-312.

[9] Miethling, B. Different but Similar: Geothermal Energy and the Role of Politics in Germany, Iceland and the United States. Zeitschrift für Energiewirtschaft 2011;35:287-296.

[10] GEA. Geothermal Energy: International Market Update. [Online] http://www.geoenergy.org/pdf/reports/gea_international_market_report_final_may_2010.pdf [Accessed August 2012]; 2010.

[11] Harvey, C, White, B. A country update of New Zealand geothermal: leading the world in generation growth since 2005. Proceedings 34th New Zealand Geothermal Workshop; 2012.

[12] Hall, S, Román, R, Cuevas, F, Sánchez, P. Are dams necessary in Patagonia? An analysis of Chile's energy future. Ocholibros Ed. [Spanish]; 2009.

[13] Dufey A. Opportunities and Domestic Barriers to Clean Energy Investment in Chile. IISD: Trade, Investment and Climate Change Series; 2010. Available in http://www.iisd.org/pdf/2010/bali_2_copenhagen_Chile_Jun2010.pdf.

[14] Sussman, D, Tucker, R. Managing the Geothermal Exploration Process with Respect to Risk and Regulations. Indonesia Geothermal Conference July 22-23, 2009.

[15] Barbier, E. Geothermal energy technology and current status: an overview. Renewable and Sustainable Energy Reviews 2002; 6:3-65.

[16] Goff, F, Janik, CJ. Geothermal systems, in Sigurdsson, H., ed., Encyclopedia of Volcanoes: San Diego, Academic Press; 2000, p. 817-834.

[17] Moeck, I. Catalog of geothermal play types based on geologic controls. Renewable and Sustainable Energy Reviews 2014; 37:867-882.

[18] Gupta, H, Roy, S. Geothermal Energy: An Alternative Resource for the 21st Century. Elsevier; 2007.

[19] Lund, J. Utilization of geothermal resources. IGA International Summer School on Direct Applications of Geothermal Energy; 2008.

[20] Bertani, R. Geothermal power generation in the world 2005-2010 update report. Geothermics 2012; 41:1-29.

[21] Lund, JW, Freeston, DH, Boyd, TL. Direct utilization of geothermal energy 2010 worldwide review. Geothermics 2011; 40:159-180.

[22] IPCC 2011 Goldstein, B, Hiriart, G, Bertani, R, Bromley, C, Gutiérrez-Negrín, L, Huenges, E, Muraoka, H, Ragnarsson, A, Tester, J, Zui, V.: Geothermal Energy. In IPCC Special Report on Renewable Energy Sources and Climate Change Mitigation [O. Edenhofer, R. Pichs-Madruga, Y. Sokona, K. Seyboth, P. Matschoss, S. Kadner, T. Zwickel, P. Eickemeier, G. Hansen, S. Schlömer, C. von Stechow (eds)], Cambridge University Press; 2011.

[23] Axelsson, G. Sustainable geothermal utilization - Case histories; definitions; research issues and modelling. Geothermics 2010; 39:283-291. 
[24] Diaz F. Estado actual de la geotermia en Chile. Seminario Latinoamericano Sobre Exploración Geotérmica (OLADE), realizado en Quito, Ecuador, del 5-9 de septiembre de 1983. SERNAGEOMIN: 21 p., 1 mapa;1983.

[25] Lahsen, A, Sepúlveda, F, Rojas, J, Palacios, C. Present Status of Geothermal Exploration in Chile. Proceedings World Geothermal Congress, Antalya, Turkey; 2005.

[26] Sánchez, P, Morata, D, Lahsen, A, Aravena, D, Parada, MA. Current status of geothermal exploration in Chile and the role of the new Andean Geothermal Center of Excellence (CEGA). Geothermal Resources Council Transactions 2011; 35:1215-1218.

[27] Japan International Cooperation Agency (JICA). Report on geothermal power development project in Puchuldiza area. JICA Report 81-50-38, 50 pp.; 1981.

[28] Cusicanqui, H, Mahon, WAJ, Ellis, AJ. The geochemistry of the El Tatio geothermal field, Northern Chile. Proceedings, Second United Nations Geothermal Symposium; 1976. Lawrence Berkeley National Laboratory, Berkeley, CA, 703-711.

[29] Raasch, G. The new geothermal law and recent geothermal activity in Chile. Geothermal Resources Council Transactions 2001; 25:549-551.

[30] Sibson, RH. Rupture interaction with fault jogs. In: Das, S., Boatwright, J., Scholz, C.H. (Eds.). Geophys. Monogr. Earthquake source mechanics 1986;37:157-167. American Geophysical Union, Washington, DC.

[31] Cox, SF. The application of failure mode diagrams for exploring the roles of fluid pressure and stress states in controlling styles of fracture-controlled permeability enhancement in faults and shear zones. Geofluids 2010; 10:217-233.

[32] Lahsen, A, Rojas, J, Morata, D, Aravena, D. Geothermal Exploration in Chile: Country Update. Proceedings World Geothermal Congress, Melbourne, Australia, 19-25 April 2015.

[33] Lahsen, A, Rojas, J, Morata, D, Aravena, D. Exploration for High-Temperature Geothermal Resources in the Andean Countries of South America. Proceedings World Geothermal Congress, Melbourne, Australia, 19-25 April 2015.

[34] Reed, A. Energy under the Andes: Benefits, Barriers to Development, and Relevant Policy Alternatives for Chile's Untapped Geothermal Resources. Master's thesis, University of Pittsburgh; 2013, 67 p.

[35] Bloomquist, RG. The Evolution of U.S. Policy Designed to Encourage Geothermal Development Provision of Access and Encouraging Project Development. Proceedings World Geothermal Congress, Antalya, Turkey; 2005.

[36] Björnsson, J. Legal, Regulatory and Energy Policy Aspects of Geothermal Energy in Iceland. Proceedings World Geothermal Congress, Florence, Italy; 1995.

[37] Coviello, M. Financing and regulation of sources of new and renewable energy: The case of geothermal. Serie medio ambiente y desarrollo $N^{\circ} 13$. ECLAC. [Spanish]; 2010.

[38] Erdogdu, E. A snapshot of geothermal energy potential and utilization in Turkey. Renewable and Sustainable Energy Reviews 2009; 13:2535-2543. 
[39] Salmon, JP, Meurice, J, Wobus, N, Stern, F, Duaime, M. Guidebook to Geothermal Power Finance. NREL Subcontract Report NREL/SR-6A20-49391, http://www.nrel.gov/docs/fy11osti/49391.pdf; 2011.

[40] Waltner, A. Permitting geothermal exploration and development projects on public and tribal lands. Geothermal Resources Council Transactions 2009;33:349-351.

[41] Hikuroa, DCH, Morgan, TKKB, Henare, M, Gravley, DM. Integrating indigenous values into geothermal development. Geothermal Resources Council Transactions 2010; 34:51-54.

[42] Pierce, SA, Malin, RA, Figueroa, E. Sustained dialogue for ground water and energy resources in Chile. Journal of Contemporary Water Research \& Education 2012; 149:76-87.

[43] Speiser, R. Energy Security and Chile: Policy Options for Sustainable Growth. USAEE Working Paper No. 08-006. Available at SSRN: http://ssrn.com/abstract=1084994; 2008.

[44] Sims, REH, Rogner, H-H, Gregory, K. Carbon emission and mitigation cost comparisons between fossil fuel, nuclear and renewable energy resources for electricity generation. Energy Policy $2003 ; 31: 1315-1326$.

[45] Rabl, A, Spadaro, JV. Environmental impacts and costs of energy. Annals of the New York Academy of Sciences 2006;1076:516-526.

[46] Pusschel, S, Palma, R, Van Campen, B. Systematic tool to plan and evaluate demand side strategies during sustained energy crises in hydrothermal power systems. International Journal of Electrical Power and Energy Systems 2015.

[47] Fuentes, VR. Geothermal Electricity Generation in Chile An Analysis from the Experience of New Zealand. Master's thesis, The University of Auckland; 2013.

[48] Püschel S, Van Campen, B. Value of Wind Development in Chilean and New Zealand Electricity Markets. Proceedings of IAEE, 2012.

[49] Palma-Behnke, R, Jiménez, G, Alarcón I. Non-Conventional Renewable Energy in the Chilean Electricity Market [Online] Available: http://www.giz.de/de/downloads/giz2012-es-energiasrenovables.pdf [Accessed 5 2014]; 2012.

[50] Systep. Tender prices for SIC - April 2014 Available http://www.systep.cl. Accessed May 2014 [Spanish]; 2014.

[51] SKM, Review of Current and Future Personnel Capability Requirements of the NZ Geothermal Industry. Available: http://www.nzgeothermal.org.nz/publications/Reports/NZGA_Geothermal_Capability_Review.p df. Accessed May 2014; 2005.

[52] IEA International Energy Agency. Renewable Energy Essentials: Geothermal [Online] Available: http://www.iea.org. [Accessed 2 2013]; 2011.

[53] De Angelis, R, Holdeman, M, Pidcock, G, Levy, W, Figueroa, H, Lyon, R. Challenges of drilling in the Chilean Altiplano. SPE/IADC Drilling Conference and Exhibition, Amsterdam, The Netherlands, 1-3 March 2011. SPE/IADC paper 140051; 2011.

[54] Branker, K. Pathak, M. J.M. Pearce J. M. A Review of Solar Photovoltaic Levelized Cost of Electricity, Renewable \& Sustainable Energy Reviews 2011;15:4470-4482. 
[55] Hernández-Moro, J, Martínez-Duart, JM. Analytical model for solar PV and CSP electricity costs: Present LCOE values and their future evolution, Renewable \& Sustainable Energy Reviews 2013; 20:119-132.

[56] Short, W, Packey, D, Holt, T. A Manual for the Economic Evaluation of Energy Efficiency and Renewable Energy Technologies. National Renewable Energy Laboratory; 1995.

[57] Lahsen, A. Geothermal exploration in Northern Chile - Summary. Circum-Pacific Energy and Mineral Resources. AAPG Memoir 1976;25:169-175.

[58] Urzua, L, Powell, T, Cumming, WB, Dobson, P. Apacheta, a new geothermal prospect in northern Chile. Geothermal Resources Council Transactions 2002; 26:65-69.

[59] Siebert, L, Simkin, T. Volcanoes of the World: an Illustrated Catalog of Holocene Volcanoes and their Eruptions. Smithsonian Institution, Global Volcanism Program Digital Information Series, GVP-3, [online] (http://www.volcano.si.edu); 2002.

[60] Benavente, O, Tassi, F, Gutierrez, F, Vaselli, O, Aguilera, F, and Reich, M, Origin of fumarolic fluids from Tupungatito Volcano (Central Chile): interplay between magmatic, hydrothermal, and shallow meteoric sources. Bulletin of Volcanology 2013; 75.

[61] Dixon, HJ, Murphy, MD, Sparks, SJ, Chávez, R, Naranjo, JA, Dunkley, PN, Young, SR, Gilbert, JS, and Pringle, MR. The Geology of Nevados de Chillán Volcano, Chile. Revista Geólogica de Chile 1999; 26(2):227-253.

[62] Melosh, G, Moore, J, Stacey, R. Natural reservoir evolution in the Tolhuaca geothermal field, southern Chile, in 37th Workshop on Geothermal Reservoir Engineering, Stanford University, Stanford, California, January 31 - February 1, 2012, SGP-TR-194;2012. 
Table 1 Synthesis of the main activities, achievements and challenges related to geothermal energy in Chile. The most relevant progress occurred in three stages led by different institutions (1) 1908-1923: Italian colony promotion; (2) 1968-1978: Chilean State investment; (3) 2000-present: Private investment with the Chilean Government acting as a regulator. NCh=Northern Chile $\mathrm{SCh}=$ Southern Chile.

\begin{tabular}{|c|c|c|c|c|}
\hline Date & Main Activities & Achivements & Challenges and issues & Funding \\
\hline $\begin{array}{c}1908- \\
1923\end{array}$ & $\begin{array}{l}\text { (1) Two wells of c.a. } 70 \mathrm{~m} \\
\text { depth were drilled at El Tatio } \\
\text { Field } \\
\text { (2) First Andean subsurface } \\
\text { geothermal fluids were } \\
\text { analyzed }\end{array}$ & $\begin{array}{l}\text { The enormous } \\
\text { resources at El } \\
\text { Tatio Geothermal } \\
\text { Field were } \\
\text { revealed, } \\
\text { becoming a } \\
\text { geothermal } \\
\text { attraction } \\
\end{array}$ & $\begin{array}{l}\text { Exploration stopped due } \\
\text { a lack of economical } \\
\text { support and technical } \\
\text { issues }\end{array}$ & $\begin{array}{l}\text { Italian Colony of } \\
\text { Antofagasta }\end{array}$ \\
\hline $\begin{array}{c}1968- \\
1978\end{array}$ & $\begin{array}{l}\text { (1) NCh: Reconnaissance } \\
\text { studies in } 20 \text { geothermal } \\
\text { areas } \\
\text { (2) NCh: Detailed geological, } \\
\text { geochemical and geophysical } \\
\text { surveys on selected areas } \\
\text { (3) Exploratory wells at } \\
\text { Puchuldiza and production } \\
\text { wells at El Tatio were drilled } \\
\text { (4) A international bidding } \\
\text { process was placed to } \\
\text { develop El Tatio Geothermal } \\
\text { Field. Many companies } \\
\text { offered. }\end{array}$ & $\begin{array}{l}\text { Training of Chilean } \\
\text { researchers on } \\
\text { geothermal } \\
\text { exploration. } \\
\text { Feasibility study at } \\
\text { El Tatio which } \\
\text { concluded that a } \\
\text { power generation } \\
\text { plant was } \\
\text { economically and } \\
\text { technically feasible }\end{array}$ & $\begin{array}{l}\text { New political scenario } \\
\text { forced energetic policies } \\
\text { to change and the } \\
\text { bidding process at El } \\
\text { Tatio was never } \\
\text { completed }\end{array}$ & CORFO and UNDP \\
\hline $\begin{array}{l}\text { late } \\
\text { 1980's }\end{array}$ & $\begin{array}{l}\text { Occasional volcanological and } \\
\text { geochemical research was } \\
\text { lead by the University of Chile, } \\
\text { foreing institutions and } \\
\text { SERNAGEOMIN }\end{array}$ & & $\begin{array}{l}\text { Exploration of energy } \\
\text { sources lead by the } \\
\text { ENAP and private } \\
\text { investors developed an } \\
\text { electric energy matrix } \\
\text { based on fossil fuels } \\
\text { and big scale } \\
\text { hydropower }\end{array}$ & $\begin{array}{l}\text { SERNAGEOMIN } \\
\text { University of Chile }\end{array}$ \\
\hline $\begin{array}{l}1990 ' s \\
-2000\end{array}$ & $\begin{array}{l}\text { (1) SCh: Geological and } \\
\text { geophysical exploration } \\
\text { conducted by ENAP and the } \\
\text { French Geothermal Company. } \\
\text { (2) SCh: Drilling of a slim } \\
\text { exploratory well in Nevados } \\
\text { de Chillán geothermal area } \\
\text { with good results } \\
\text { (3) NCh: Geothermal } \\
\text { explotation was resumed by a } \\
\text { joint venture between ENAP } \\
\text { and UNOCAL Corp, from } \\
1995 \text { to } 1999\end{array}$ & $\begin{array}{l}\text { Development of a } \\
\text { new regulatory } \\
\text { scenario for the } \\
\text { geothermal energy } \\
\text { encouraged by } \\
\text { good results on } \\
\text { exploration }\end{array}$ & $\begin{array}{l}\text { No legal framework for } \\
\text { private development of } \\
\text { geothermal resources }\end{array}$ & $\begin{array}{l}\text { ENAP and } \\
\text { international } \\
\text { private companies }\end{array}$ \\
\hline \multirow[b]{2}{*}{$\begin{array}{l}2000- \\
\text { present }\end{array}$} & $\begin{array}{l}\text { (1) In } 2000 \text { the regulatory } \\
\text { framework was enacted (Law } \\
19.657 \text { ) resulting in an active } \\
\text { bidding process granting. }\end{array}$ & $\begin{array}{l}\text { High investment } \\
\text { focused in } \\
\text { electrical } \\
\text { generation. }\end{array}$ & $\begin{array}{l}\text { The absence of a long } \\
\text { term energy policy to } \\
\text { guide the optimal } \\
\text { decision of source and } \\
\text { location for energy } \\
\text { projects. }\end{array}$ & \multirow[b]{2}{*}{$\begin{array}{l}\text { Local and foreign } \\
\text { private investment }\end{array}$} \\
\hline & $\begin{array}{l}\text { (2) Production diameter deep } \\
\text { exploration wells }(\geq 2500 \mathrm{~m}) \\
\text { were drilled in Tolhuaca and } \\
\text { Pampa Apacheta }\end{array}$ & $\begin{array}{l}\text { Tolhuaca } \\
\text { Geothermal Field is } \\
\text { under evaluation } \\
\text { for constructing a } \\
70 \mathrm{MW} \text { power plant } \\
\text { Pampa Apacheta is } \\
\text { planning the } \\
\text { construction of a } \\
50 \mathrm{MW} \text { power plant } \\
\text { for } 2016\end{array}$ & $\begin{array}{l}\text { High cost of drilling due } \\
\text { to the scarcity of } \\
\text { geothermal drill rigs and } \\
\text { trained crews }\end{array}$ & \\
\hline
\end{tabular}


(3) Creation of a geothermal department in the SERNAGEOMIN and the Andean Geothermal Center of Excellence (CEGA) in University of Chile
Quantitative and qualitative improvement of the research of geothermal energy in Chile
Much of geological data

is owned by private

companies who are not

keen to collaborate in

research

Table 2 Main geothermal exploration projects, their geothermal context and current status.

\begin{tabular}{|c|c|c|c|c|c|c|c|}
\hline & \multicolumn{3}{|c|}{ Location } & \multirow[b]{2}{*}{$\begin{array}{l}\text { Surface activity } \\
\text { and temperature }\end{array}$} & \multirow[b]{2}{*}{ Geologic Enviroment } & \multirow[b]{2}{*}{$\begin{array}{l}\text { Current } \\
\text { Activities in } \\
\text { exploration }\end{array}$} & \multirow[b]{2}{*}{ Company } \\
\hline $\begin{array}{l}\text { Geothermal } \\
\text { Area }\end{array}$ & Lat & Lon & Elevation & & & & \\
\hline $\begin{array}{l}\text { Puchuldiza } \\
1\end{array}$ & $19^{\circ} 23^{\prime S}$ & $69^{\circ} 01 \mathrm{~W}$ & 4250 & $\begin{array}{l}\text { Hot springs, } \\
\text { fumaroles, mud } \\
\text { pools, altered } \\
\text { zones, silica } \\
\text { deposits, boiling } \\
\text { pools ; } 20-90 \cong \mathrm{O} \\
\end{array}$ & $\begin{array}{l}\text { Volcano-tectonic } \\
\text { depression surrounded } \\
\text { by Plio-Pleistocene } \\
\text { volcanoes [57] }\end{array}$ & $\begin{array}{l}\text { Slim holes } \\
\text { have been } \\
\text { drilled }\end{array}$ & $\begin{array}{l}\text { Mighty } \\
\text { River } \\
\text { Power } \\
\text { Chile }\end{array}$ \\
\hline $\begin{array}{l}\text { Apacheta / } \\
\text { Cerro } \\
\text { Pabellón }\end{array}$ & $21^{\circ} 51^{\prime} \mathrm{S}$ & $68^{\circ} 08^{` W}$ & 5200 & Fumaroles; $118^{\circ} \mathrm{C}$ & $\begin{array}{l}\text { Plio-Pleistocene volcanic } \\
\text { complex located within a } \\
\text { NW-trending graben [58]. }\end{array}$ & $\begin{array}{l}\text { Planning } \\
\text { production } \\
\text { for } 2017 \text { (50 } \\
\text { MWe) }\end{array}$ & $\begin{array}{l}\text { Geotérmica } \\
\text { del Norte }\end{array}$ \\
\hline $\begin{array}{l}\text { Surire - } \\
\text { Polloquere } \\
1\end{array}$ & $18^{\circ} 55^{\prime S}$ & $68^{\circ}-59^{` W}$ & 4300 & $\begin{array}{l}\text { Fumaroles, hot } \\
\text { springs, altered } \\
\text { zones, silica } \\
\text { deposits, boiling } \\
\text { pools ; } 20-80^{\circ} \mathrm{C}\end{array}$ & $\begin{array}{l}\text { Plio-Pleistocene dacitic } \\
\text { volcanoes [57] }\end{array}$ & $\begin{array}{l}\text { Slim holes } \\
\text { have been } \\
\text { drilled }\end{array}$ & $\begin{array}{l}\text { Energía } \\
\text { Andina } \\
\text { S.A. }\end{array}$ \\
\hline Irruputuncu & $20^{\circ} 44^{\prime S}$ & $68^{\circ} 33^{\prime} \mathrm{W}$ & 5150 & $\begin{array}{l}\text { Fumaroles, hot } \\
\text { springs; }>100^{\circ} \mathrm{C}\end{array}$ & $\begin{array}{l}\text { Stratovolcano within a } \\
\text { NE-SW-trending chain of } \\
\text { volcanoes constructed } \\
\text { within the collapse scarp } \\
\text { of a Holocene debris } \\
\text { avalanche [59] }\end{array}$ & $\begin{array}{l}\text { Slim holes } \\
\text { have been } \\
\text { drilled }\end{array}$ & $\begin{array}{l}\text { Minera } \\
\text { Doña Inés } \\
\text { de } \\
\text { Collahuasi }\end{array}$ \\
\hline $\begin{array}{l}\text { Pampa } \\
\text { Lirima }\end{array}$ & $19^{\circ} 51^{\prime} \mathrm{S}$ & $68^{\circ} 56 \mathrm{~W}$ & 3900 & $\begin{array}{l}\text { Geysers, hot } \\
\text { springs, fumaroles, } \\
\text { altered } \\
\text { zones, deposits, } \\
\text { boiling pools ; >86 } \\
{ }^{\circ} \mathrm{C}\end{array}$ & $\begin{array}{l}\text { Upper Tertiary } \\
\text { sedimentary and volcanic } \\
\text { rocks [57] }\end{array}$ & $\begin{array}{l}\text { Surficial } \\
\text { exploration. } \\
\text { Slim holes } \\
\text { drilling are } \\
\text { planned }\end{array}$ & $\begin{array}{l}\text { Energía } \\
\text { Andina } \\
\text { S.A. }\end{array}$ \\
\hline El Tatio & $22^{\circ} 20^{\prime} S$ & $68^{\circ} 01 \mathrm{~W}$ & 4300 & $\begin{array}{l}\text { Geysers, hot } \\
\text { springs, fumaroles, } \\
\text { mud pools, altered } \\
\text { zones, silica } \\
\text { deposits, boiling } \\
\text { pools ; } 86^{\circ} \mathrm{C}\end{array}$ & $\begin{array}{l}\text { N-S graben filled by } \\
\text { Miocene to Pleistocene } \\
\text { ignimbrites and andesitic } \\
\text { volcanoes [57] }\end{array}$ & $\begin{array}{l}\text { Exploration } \\
\text { stopped }\end{array}$ & $\begin{array}{l}\text { Geotérmica } \\
\text { del Norte }\end{array}$ \\
\hline Tinguiririca & $35^{\circ} 48^{\prime \prime S}$ & $68^{\circ} \mathrm{W}$ & 4200 & $\begin{array}{l}\text { Hot springs, } \\
\text { fumaroles }\end{array}$ & $\begin{array}{l}\text { Holocene scoria cones } \\
\text { constructed along a NNE- } \\
\text { SSW fissure over an } \\
\text { eroded Pleistocene } \\
\text { stratovolcano [59] }\end{array}$ & $\begin{array}{l}\text { Slim holes } \\
\text { have been } \\
\text { drilled }\end{array}$ & $\begin{array}{l}\text { Energía } \\
\text { Andina } \\
\text { S.A. }\end{array}$ \\
\hline Calabozos & $35^{\circ} 30^{\prime} \mathrm{S}$ & $70^{\circ} 30^{` W}$ & 2600 & $\begin{array}{l}\text { Hot springs, } \\
\text { fumaroles, mud } \\
\text { pools, altered zones } \\
\text {; 20-90 ㄷ }\end{array}$ & $\begin{array}{l}\text { Plio-Pleistocene basaltic } \\
\text { to dacitic volcanoes. [60] }\end{array}$ & $\begin{array}{l}\text { Slim holes } \\
\text { have been } \\
\text { drilled }\end{array}$ & $\begin{array}{l}\text { Empresa } \\
\text { Nacional } \\
\text { de } \\
\text { Geotermia } \\
\text { S.A. }\end{array}$ \\
\hline $\begin{array}{l}\text { Laguna del } \\
\text { Maule }\end{array}$ & $36 \div 1$ S & $70^{\circ} 35 \mathrm{~W}$ & 2400 & $\begin{array}{l}\text { Fumaroles, hot } \\
\text { springs, steaming } \\
\text { ground, bubbling } \\
\text { pools; } 93^{\circ}-120^{\circ} \mathrm{C}\end{array}$ & $\begin{array}{l}\text { Basaltic to rhyolitic } \\
\text { Holocene volcanoes and } \\
\text { blocky lava flows [60] }\end{array}$ & $\begin{array}{l}\text { Slim holes } \\
\text { have been } \\
\text { drilled. Deep } \\
\text { exploration } \\
\text { wells are } \\
\text { planned } \\
(2015)\end{array}$ & $\begin{array}{l}\text { Compañía } \\
\text { de Energía } \\
\text { Limitada }\end{array}$ \\
\hline
\end{tabular}




\begin{tabular}{|c|c|c|c|c|c|c|c|}
\hline Chillán & $36^{\circ} 51^{\prime} \mathrm{S}$ & $71^{\circ} 22^{\prime} \mathrm{W}$ & 3200 & $\begin{array}{l}\text { Fumaroles, hot } \\
\text { springs, mud pools, } \\
\text { altered zones; } 90^{\circ} \mathrm{C}\end{array}$ & $\begin{array}{l}\text { N30W trendind basaltic to } \\
\text { dacitic late Pleistocene to } \\
\text { Holocene volcanic } \\
\text { complex [61] }\end{array}$ & $\begin{array}{l}\text { Current } \\
\text { exploration } \\
\text { stopped. } \\
\text { Slim holes } \\
\text { have been } \\
\text { drilled. }\end{array}$ & $\begin{array}{l}\text { Empresa } \\
\text { Nacional } \\
\text { de } \\
\text { Geotermia } \\
\text { S.A. }\end{array}$ \\
\hline $\begin{array}{l}\text { Tolhuaca / } \\
\text { San } \\
\text { Gregorio }\end{array}$ & $38^{\circ} 18^{\prime} S$ & $71^{\circ} 38^{\prime} W$ & 2700 & $\begin{array}{l}\text { Fumaroles, hot } \\
\text { springs, } \\
\text { propylitically and } \\
\text { argilically altered } \\
\text { zones; } 94 \stackrel{\circ}{-} \text {. }\end{array}$ & $\begin{array}{l}\text { Volcanic flows and } \\
\text { breccias near the inactive } \\
\text { late-Pleistocene to } \\
\text { Holocene Tolhuaca } \\
\text { Volcano [62] }\end{array}$ & $\begin{array}{l}\text { Planning } \\
\text { production }\end{array}$ & $\begin{array}{l}\text { Mighty } \\
\text { River } \\
\text { Power } \\
\text { Chile }\end{array}$ \\
\hline
\end{tabular}

Table 3 Results of the valuation for advantages of geothermal energy by the Industry (I), Government (G) and Academia/Other (A/O) and the Average of All Groups (Avg) with a scale from 1 (important) to 5 (important).

\begin{tabular}{|l|cccc|}
\hline & I & G & A/O & Avg. \\
\hline Advantage & & & & \\
\hline High Capacity factor & 4.8 & 5.0 & 5.0 & 4.9 \\
Domestic resource & 4.4 & 5.0 & 5.0 & 4.8 \\
Abundant in Chile & 4.5 & 4.8 & 5.0 & 4.8 \\
Versatile resource (heat and electric uses) & 4.4 & 5.0 & 4.8 & 4.7 \\
Low environmental impact & 4.5 & 5.0 & 4.3 & 4.6 \\
Geothermal technology is mature & 4.4 & 4.5 & 4.5 & 4.5 \\
Can be develop in a Modular way & 4.2 & 4.8 & 4.3 & 4.4 \\
Contribute the international goals to diminish & & & & \\
pollution & 4.4 & 4.3 & 4.5 & 4.4 \\
Resources close to mining industry & 4.1 & 4.5 & 4.5 & 4.4 \\
Supports local economic development & 3.8 & 4.0 & 5.0 & 4.3 \\
Creates jobs and economic growth & 3.6 & 4.3 & 4.8 & 4.2 \\
Competitive costs & 3.6 & 3.3 & 4.0 & 3.6 \\
\hline
\end{tabular}

Table 4: Selected results of the valuation for barriers and incentives to geothermal development by the Industry (I), Government $(\mathrm{G})$ and Academia/Other $(\mathrm{A} / \mathrm{O})$ and the Average of All Groups (Avg). Only the most valuated barrier and incentives are shown. OQR-n: Open Question Response - number of mentions. Policy solution feasibility is based on the level of agreement on barrier and solution e.g. Medium= Agreement on the barrier but disagreement on solution

\begin{tabular}{|c|c|c|c|c|c|c|c|c|c|c|c|}
\hline \multirow{2}{*}{ Type } & \multirow{2}{*}{ Barriers } & \multicolumn{4}{|c|}{$\begin{array}{l}\text { Survey Results: } \\
\text { Barrier Strength* }\end{array}$} & \multirow{2}{*}{ Proposal } & \multicolumn{4}{|c|}{$\begin{array}{c}\text { Survey Results: } \\
\text { Proposal Strength* }\end{array}$} & \multirow{2}{*}{$\begin{array}{l}\text { Policy } \\
\text { solution } \\
\text { feasibility }\end{array}$} \\
\hline & & I & G & $A / O$ & Avg. & & I & G & $A / O$ & Avg. & \\
\hline \multirow{3}{*}{$\begin{array}{l}\text { Financial \& } \\
\text { Economical }\end{array}$} & \multirow{3}{*}{$\begin{array}{l}\text { All of the Risk Falls on } \\
\text { the Investors. Extremely } \\
\text { high costs and risks } \\
\text { associated with } \\
\text { exploration process. No } \\
\text { guarantee of viable } \\
\text { resource for exploitation. }\end{array}$} & \multirow{3}{*}{4.4} & \multirow{3}{*}{4.1} & \multirow{3}{*}{4.0} & \multirow{3}{*}{4.2} & $\begin{array}{c}\text { Subsidizes } \\
\text { partially the } \\
\text { exploration phase } \\
\text { related to } \\
\text { unsuccessful } \\
\text { drilling. } \\
\end{array}$ & 4.4 & 4.1 & 4.0 & 4.2 & High \\
\hline & & & & & & $\begin{array}{c}\text { Feed-in tariff with } \\
15 \text { to } 20 \text { year } \\
\text { window }\end{array}$ & 4.2 & 3.3 & 4.3 & 3.9 & Med \\
\hline & & & & & & $\begin{array}{c}\text { Offer tax } \\
\text { benefits/incentives } \\
\text { for geothermal } \\
\text { generation } \\
\end{array}$ & 4.1 & 3.3 & 4.3 & 3.9 & Med \\
\hline
\end{tabular}




\begin{tabular}{|c|c|c|c|c|c|c|c|c|c|c|c|}
\hline & & & & & & \multicolumn{2}{|l|}{ companies } & \multicolumn{2}{|l|}{. } & & \\
\hline & $\begin{array}{c}\text { Lack of drilling } \\
\text { providers Only two } \\
\text { Firms Available That } \\
\text { Provide Necessary } \\
\text { Exploration Equipment. } \\
\text { Drilling costs remain very } \\
\text { high. }\end{array}$ & 4.4 & 4.8 & 4.0 & 4.4 & $\begin{array}{l}\text { Provide financial } \\
\text { incentives to } \\
\text { attract more service } \\
\text { providers to the } \\
\text { market; Also } \\
\text { support logistical } \\
\text { and technical } \\
\text { needs. }\end{array}$ & 3.8 & 4.5 & 4.3 & 4.2 & Med \\
\hline & $\begin{array}{c}\text { Some Geothermal } \\
\text { Resources are in } \\
\text { Remote Areas. These do } \\
\text { not have adequate } \\
\text { infrastructure and/or } \\
\text { access to the electrical } \\
\text { grid }\end{array}$ & 4.5 & 4.5 & 4.5 & 4.5 & $\begin{array}{l}\text { Ensure necessary } \\
\text { transmission lines } \\
\text { and infrastructure }\end{array}$ & 4.6 & 5.0 & 4.3 & 4.6 & High \\
\hline \multirow{7}{*}{$\begin{array}{l}\text { Legal \& } \\
\text { regulatory }\end{array}$} & $\begin{array}{l}\text { Speculation. The } \\
\text { regulatory framework has } \\
\text { allowed that many } \\
\text { speculators obtain } \\
\text { geothermal concessions, } \\
\text { delaying largely the } \\
\text { development of } \\
\text { interesting prospects. }\end{array}$ & \multicolumn{4}{|c|}{ OQR- 6} & $\begin{array}{c}\text { Consider technical } \\
\text { criteria and a } \\
\text { company's project } \\
\text { history in } \\
\text { geothermal } \\
\text { concession granting } \\
\text { process }\end{array}$ & \multicolumn{4}{|c|}{ OQR- 6} & Med \\
\hline & \multirow{2}{*}{$\begin{array}{l}\text { Lack of clear and } \\
\text { comprehensive legal } \\
\text { framework to regulate } \\
\text { disputes between } \\
\text { geothermal developer } \\
\text { and other persons who } \\
\text { own the rights to other } \\
\text { resources within the } \\
\text { concession }\end{array}$} & \multirow{2}{*}{4.1} & \multirow{2}{*}{2.8} & \multirow{2}{*}{4.3} & \multirow{2}{*}{3.7} & $\begin{array}{l}\text { Government act as } \\
\text { a mediator or } \\
\text { create a new } \\
\text { regulatory } \\
\text { framework } \\
\end{array}$ & 3.8 & 3.0 & 4.5 & 3.8 & Low \\
\hline & & & & & & $\begin{array}{c}\text { Incorporate ILO } \\
\text { Convention } 169 \text { on } \\
\text { indigenous rights } \\
\text { into domestic } \\
\text { geothermal law. }\end{array}$ & \multicolumn{4}{|c|}{ OQR- 4} & Low \\
\hline & $\begin{array}{l}\text { Concessions for One } \\
\text { Resource May Be } \\
\text { Granted to More Than } \\
\text { One Company }\end{array}$ & 4.4 & 4.3 & 4.0 & 4.2 & $\begin{array}{l}\text { Grant concessions } \\
\text { in a manner that } \\
\text { assures that one } \\
\text { specific geothermal } \\
\text { resource is not } \\
\text { divided in many } \\
\text { companies. }\end{array}$ & 4.6 & 4.4 & 4 & 4.3 & High \\
\hline & $\begin{array}{c}\text { Environmental Impact } \\
\text { Studies Are Not } \\
\text { Uniform and Create } \\
\text { Project Delays }\end{array}$ & \multicolumn{4}{|c|}{ OQR- 8} & $\begin{array}{l}\text { Train evaluators to } \\
\text { assess the unique } \\
\text { nature of } \\
\text { geothermal } \\
\text { projects. Require } \\
\text { impact studies prior } \\
\text { to exploration for a } \\
\text { 'baseline' } \\
\text { environmental } \\
\text { conditions. }\end{array}$ & \multicolumn{4}{|c|}{ OQR- 8} & Low \\
\hline & $\begin{array}{l}\text { Inflexible Concession } \\
\text { Requirements on length } \\
\text { and dimensions }\end{array}$ & \multicolumn{4}{|c|}{ OQR- 8} & $\begin{array}{c}\text { Extend period of } \\
\text { concession by the } \\
\text { unique } \\
\text { environmental } \\
\text { and/or climate } \\
\text { conditions and } \\
\text { adjust the shape of } \\
\text { the concession } \\
\text { according to the } \\
\text { needs e.g. those } \\
\text { along the border. }\end{array}$ & \multicolumn{4}{|c|}{ OQR- 8} & Low \\
\hline & $\begin{array}{l}\text { Environmental Impact } \\
\text { Studies Are Not } \\
\text { Uniform and Create } \\
\text { Project Delays. Those } \\
\text { who conduct and } \\
\text { evaluate the studies are }\end{array}$ & \multicolumn{4}{|c|}{ OQR- 8} & $\begin{array}{c}\text { Train evaluators to } \\
\text { assess the unique } \\
\text { nature of } \\
\text { geothermal } \\
\text { projects. Require } \\
\text { impact studies prior }\end{array}$ & \multicolumn{4}{|c|}{ OQR- 8} & Low \\
\hline
\end{tabular}




\begin{tabular}{|c|c|c|c|c|c|c|c|c|c|c|c|}
\hline & $\begin{array}{c}\text { often not geothermal } \\
\text { experts. }\end{array}$ & & & & & $\begin{array}{l}\text { to exploration for a } \\
\text { 'baseline' } \\
\text { environmental } \\
\text { conditions. }\end{array}$ & & & & & \\
\hline \multirow{3}{*}{ Institutional } & $\begin{array}{l}\text { Lack of Formal National } \\
\text { Plan for Geothermal } \\
\text { Development }\end{array}$ & 4.4 & 3.8 & 4.5 & 4.2 & $\begin{array}{l}\text { Provide clear vision } \\
\text { of the role } \\
\text { geothermal energy } \\
\text { will play in Chile's } \\
\text { future energy mix } \\
\end{array}$ & 4.5 & 4.8 & 4.5 & 4.6 & Med \\
\hline & $\begin{array}{c}\text { Lack of Sufficient } \\
\text { Human Resources } \\
\text { Dedicated to Geothermal } \\
\text { Regulation and } \\
\text { Promotion in Government } \\
\text { Institutions }\end{array}$ & \multicolumn{4}{|c|}{ OQR- 11} & $\begin{array}{l}\text { Consolidate } \\
\text { geothermal } \\
\text { management and } \\
\text { regulation in one } \\
\text { office. Ensure that } \\
\text { relevant } \\
\text { government } \\
\text { agencies are } \\
\text { sufficiently and } \\
\text { qualifiedly staffed } \\
\end{array}$ & \multicolumn{4}{|c|}{ OQR- 11} & High \\
\hline & $\begin{array}{l}\text { Some Concessions } \\
\text { Granted After a Lengthy } \\
\text { Approval Process }\end{array}$ & 4.4 & 3.4 & 4.4 & 4.1 & $\begin{array}{l}\text { Provide additional } \\
\text { qualified human } \\
\text { resources to speed } \\
\text { up concessions } \\
\text { process } \\
\end{array}$ & 4.3 & 3.6 & 4.3 & 4.1 & Med \\
\hline \multirow{5}{*}{$\begin{array}{l}\text { Educational, } \\
\text { Information } \\
\text { \& Social }\end{array}$} & $\begin{array}{l}\text { No Mature Center of } \\
\text { Research. There no } \\
\text { center with a long history } \\
\text { of research which can } \\
\text { support the industry. } \\
\text { CEGA is only two years } \\
\text { old }\end{array}$ & 3.6 & 4.3 & 4.8 & 4.2 & $\begin{array}{c}\text { Promote } \\
\text { information } \\
\text { sharing between all } \\
\text { actors in the sector } \\
\text { and the universities. } \\
\text { Strongly support } \\
\text { centers of research, } \\
\text { such as CEGA. } \\
\end{array}$ & 4.1 & 4.4 & 4.3 & 4.3 & Med \\
\hline & \multirow{2}{*}{$\begin{array}{l}\text { No Central Source of } \\
\text { Geothermal Data. Much } \\
\text { data about resources } \\
\text { remains in the hands of } \\
\text { private companies. } \\
\text { Neither the government } \\
\text { nor academic institutions } \\
\text { have complete access to } \\
\text { the data. }\end{array}$} & \multirow[b]{2}{*}{3.3} & \multirow[b]{2}{*}{4.6} & \multirow[b]{2}{*}{4.5} & \multirow[b]{2}{*}{4.1} & $\begin{array}{c}\text { Engage in a } \\
\text { national study of } \\
\text { geothermal } \\
\text { resources with } \\
\text { sufficient and long } \\
\text { term funds } \\
\end{array}$ & 3.5 & 4.9 & 4.3 & 4.2 & Med \\
\hline & & & & & & $\begin{array}{c}\text { Require } \\
\text { companies to } \\
\text { provide the results } \\
\text { of exploration if a } \\
\text { concession is } \\
\text { abandoned by a } \\
\text { company or if a } \\
\text { concession for } \\
\text { exploitation is } \\
\text { granted } \\
\end{array}$ & 3.1 & 4.3 & 4.3 & 3.9 & Low \\
\hline & \multirow[b]{2}{*}{$\begin{array}{l}\text { Communities may } \\
\text { percieve Geothermal } \\
\text { Exploration/Exploitation } \\
\text { as a Threat to existing } \\
\text { economic, environmental, } \\
\text { and social conditions. }\end{array}$} & \multirow[b]{2}{*}{4.3} & \multirow[b]{2}{*}{4.3} & \multirow[b]{2}{*}{4.8} & \multirow[b]{2}{*}{4.5} & $\begin{array}{c}\text { Provide a } \\
\text { framework for } \\
\text { economic and } \\
\text { social } \\
\text { development in } \\
\text { communities near } \\
\text { geothermal projects } \\
\end{array}$ & 3.8 & 4.8 & 4.5 & 4.4 & Med \\
\hline & & & & & & $\begin{array}{l}\text { Create public } \\
\text { awareness } \\
\text { campaign to } \\
\text { effectively } \\
\text { demonstrate } \\
\text { potential } \\
\text { environmental, } \\
\text { economic, and } \\
\text { social benefits of } \\
\text { geothermal energy } \\
\text { production. }\end{array}$ & \multicolumn{4}{|c|}{ OQR- 13} & High \\
\hline
\end{tabular}


Figures

Figure 1

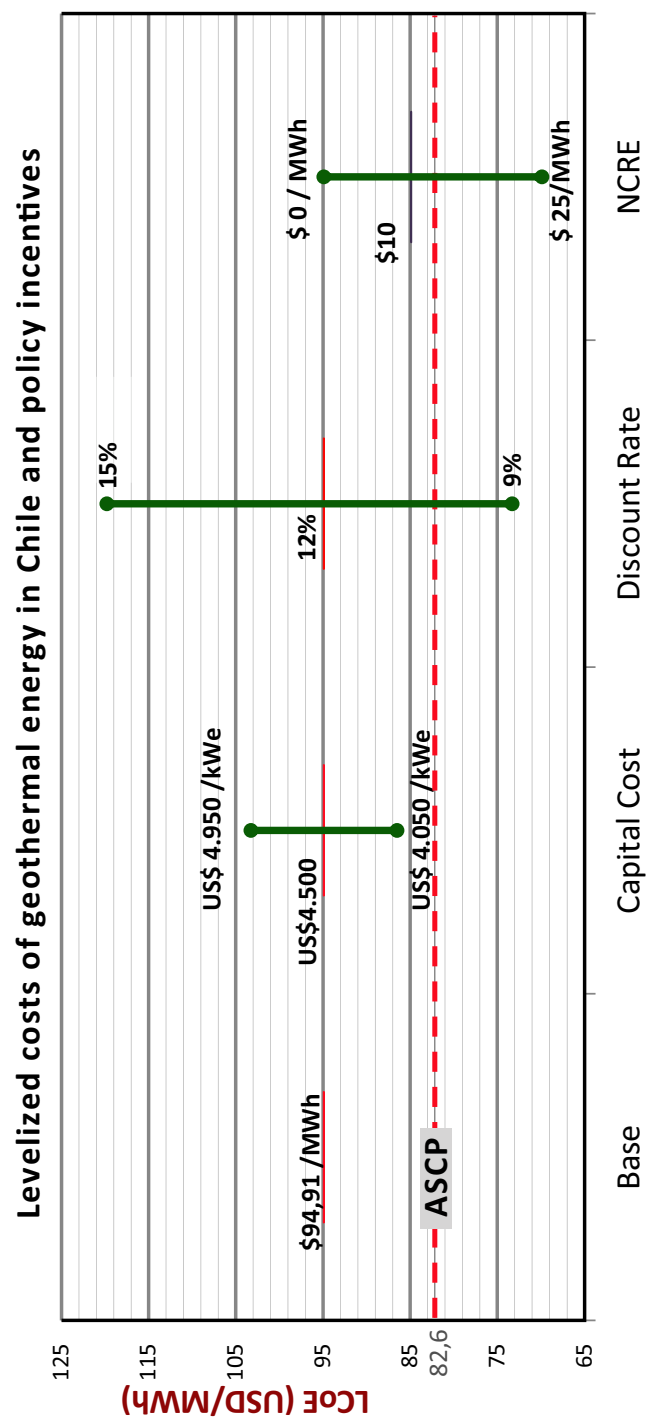




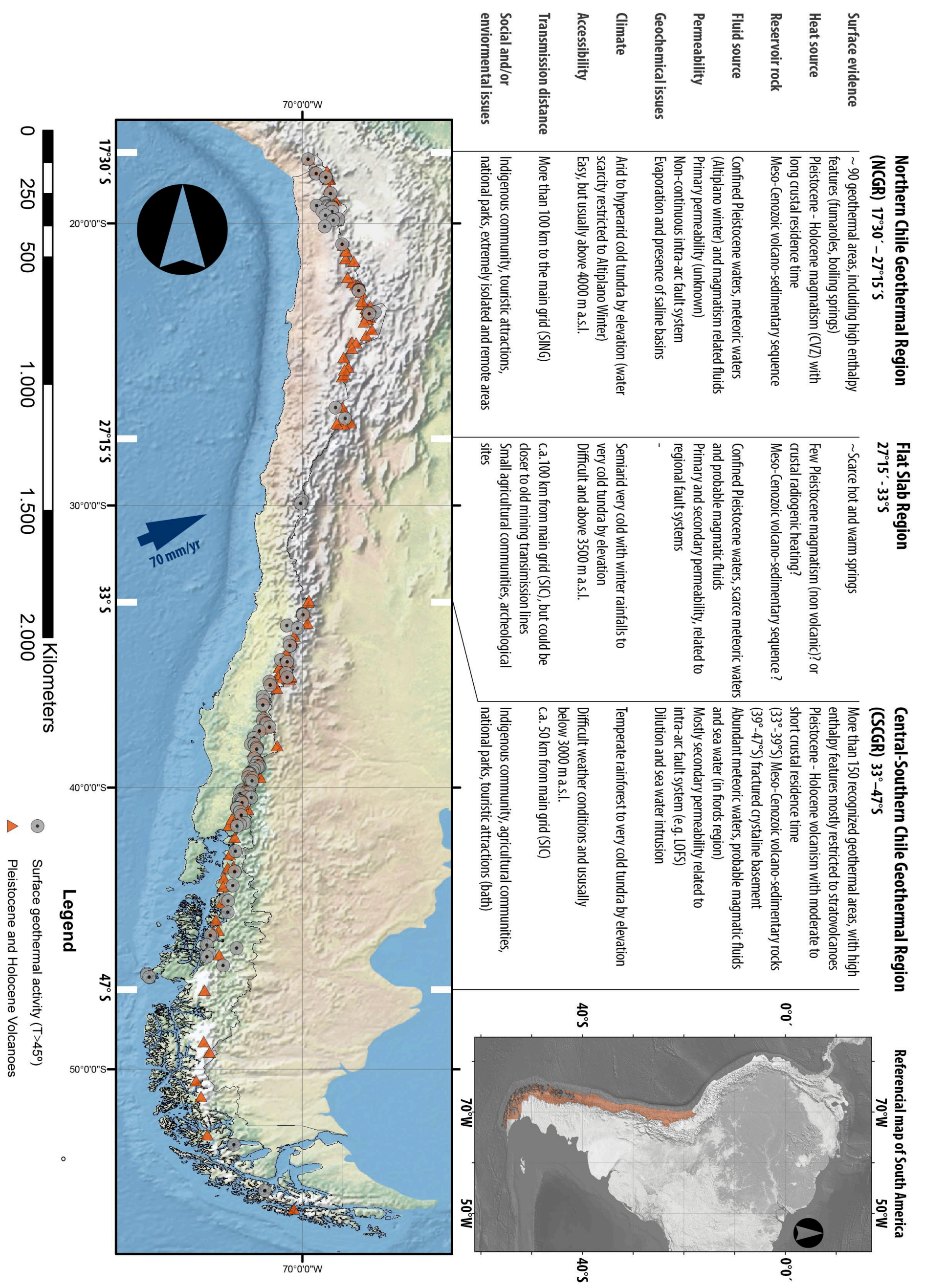



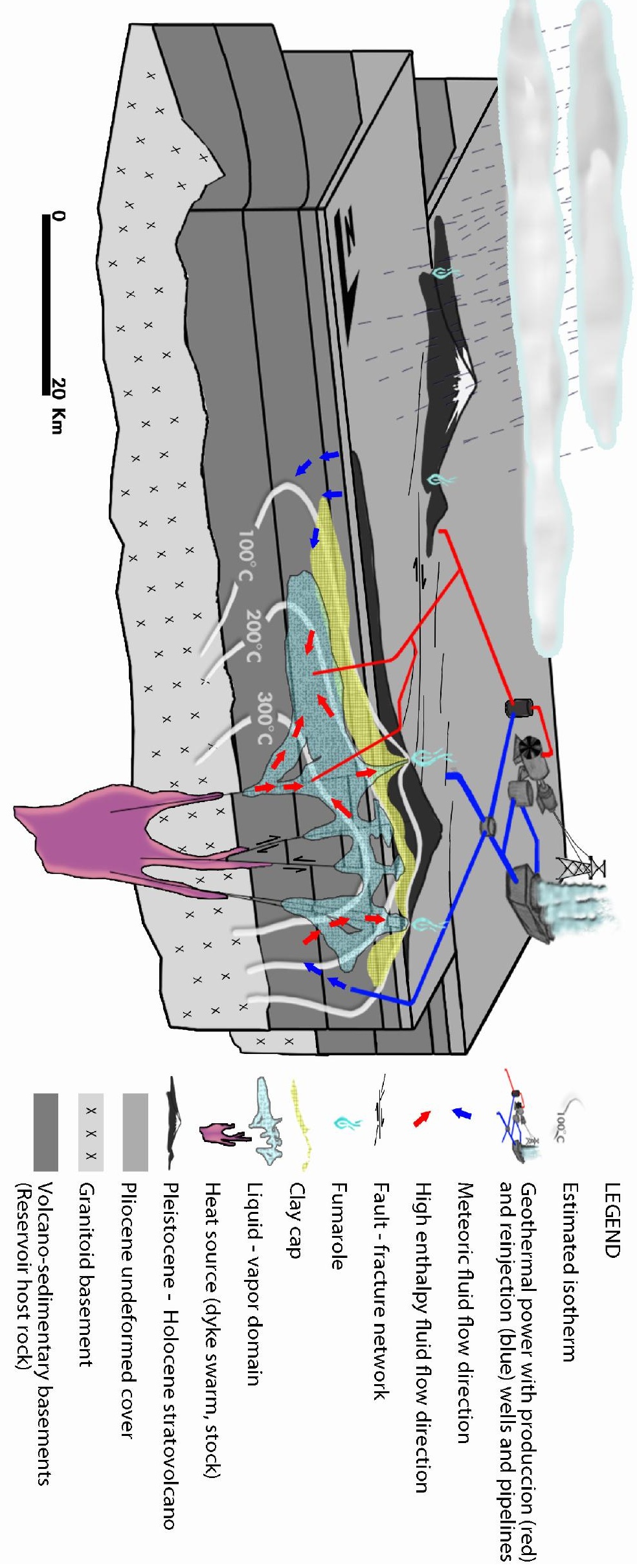